\title{
The Economic, Social, and Environmental Sustainability of Brazil Applied to Holding Eletrobras on Hydroelectric Power Generation Segment*
}

\author{
Kalink Shangred Silva Almeida \\ University of Trás-os-Montes and Alto Douro (UTAD), Vila Real, Portugal
}

\begin{abstract}
This paper aims to present a literature review on the topic of economic, social, and environmental sustainability of Brazil in hydroelectric power generation segment. This theme is very important, given the challenges facing the energy industry to find a balance or trade-off among economic, social, and environmental dimensions, also known as triple sustainability. The hydropower industry looking for a solution to these challenges involving different stakeholders who seek to defend their interests; this solution should be able to evaluate its performance, ensure continuous improvement over the years to be applied in the future under the guidance of the holding company Eletrobras. The implementation of hydroelectric generating major impacts on ecosystems, society and the economic system, but also helps to reduce energy dependence of the country is a renewable and clean energy. The solution to these problems is to try to encourage adoption of various practices and redress mechanisms, such as the introduction of tax incentives to promote environmental responsibility in business in finding a sustainable balance. One goal of this work is to contribute to the understanding of sustainability in the hydropower industry to help promote sustainability in this industry in order to promote sustainable development in the future.
\end{abstract}

Keywords: energy, environment, public policy, social and environmental impacts, sustainable development

Nowadays, sustainability is a very controversial theme, although it is a relatively simple concept, because it is always associated with environmental issues, but it is also a complex issue in terms of treatment because it is not restricted only to issues of the environment, since it covers various areas involving economic, social environmental issues combined with the so-called sustainability tripod (Soini \& Birkeland, 2014; Schrettle Hinz, Scherrer-Rathje, \& Friedli, 2014; Golini, Longoni, \& Cagliano, 2014).

The consequences of the degradation of natural resources that have been developing over time are now in sight (Pereira, 2011; Tollefson \& Gilbert, 2012; Liu, Zuo, Sun, Zillante, \& Chen, 2013). These effects manifest themselves in a catastrophic worldwide, as for example, through climate change (Rigby et al., 2013; Xu, Zaelke, Velders, \& Ramanathan, 2013b; Medina, 2013).

Climate change has been causing anomalous phenomena to nature, like abundant rain in certain regions,

\footnotetext{
* The author wants to thank the financial suport of the University of Trás-os-Montes and Alto Douro (UTAD), Research Unity of the Department of Management and Economics.

Corresponding author: Kalink Shangred Silva Almeida, Ph.D. candidate in management, formed on administration in trade exterior, works in the area of research and post-graduate research in the Department of Economics, Sociology and Management, University of Trás-os-Montes and Alto Douro (UTAD); research fields: economics, sociology, and management. E-mail: kalinkbr@hotmail.com.
} 
long periods of drought, frost, typhoons, among others, whose consequences will worsen even more impacts on the ecosystem, mainly to the society that depends on natural resources for survival (Matthew \& Nigel, 2011; Fang \& Deng, 2011).

Aware of the fact that environmental degradation undermines the sustainability, civil society, governmental entities, and the hydroelectric sector, the true object of this study begin to realize the importance of adapting production practices and provision of service in order to carry out their activities in a manner less aggressive to the environment, namely, the importance of applying a management focused on social issues and the environment (Matthew \& Nigel, 2011; Fang \& Deng, 2011).

Consequently, in terms of organization, this paper presents beyond this introduction, the second section dedicated to exposing the problems of sustainability, the third section presents a literature review (state of art), and the fourth section ends where we leave a brief conclusion and some policy recommendations.

\section{The Problems of Sustainability}

\section{Initial Considerations}

Sustainability directly influences various distinct and correlated areas, e.g., the reproduction and survival of living beings, the participation of the government through deliberations and grants, and the aspects of environmental management that involves the analysis of the viability of the projects, for which, takes the responsibility of outlining future prospects, among other interrelated factors that are involved in the process whose main objective is to find the interaction among the contexts faced and balance needed to preserve human life (Pereira, 2011; Pascual, Garmendia, Phelps, \& Ojea, 2013; Alexander \& Rutherford, 2014).

These environmental principles are consolidated into concrete practices through activities developed by the companies to use stocks in an efficient and sustainable leadership and management. It is important to consider the attributions of the hydroelectric companies bearing in mind that generate benefits for all stakeholders and that while developing practices that affect the environment, still develop techniques and studies that protect the environment (Fang \& Deng, 2011; Eletrobras, 2012).

Given all impacts caused by the destructive and predatory practices of man on Earth and the growing need for natural resource consumption by society, companies began to incorporate the environmental variable, through the implantation of the environmental management system, which provides the necessary mechanisms for the adequacy of company's activities toward the environment (Eletrobras, 2011; Eletrobras, 2012).

In this study, the author will examine the concerns about the economic, environmental, and social issues from the analysis of the Brazilian hydroelectric sector, in particular the Brazilian Electrical Main Central (Centrais Elétricas Brasileiras S.A.) or Holding Company Eletrobras, so known because it controls the Brazilian electric sector. The focus of this study lies in the follow-up to the generation of hydropower.

Commonly, companies are adopting various strategic mechanisms to deal with the environmental variables, combined with management practices, such as ecological marketing, seeking to highlight the image of the company and its products, linked to social and environmental actions, with the purpose of distinguishing the competitive market (Heinimann, 2010; Weilkiens, Weiss, \& Grass, 2011; Wiengarten, Pagell, \& Fynes, 2013; Koenig-Lewis, Palmer, Dermody, \& Urbye, 2014; Mariadoss, Tansuhaj, \& Mouri, 2011).

Hydroelectric companies of Brazil, with the support of the federal government, demonstrate openness their behavior and actions in the media as well as in other media corporations in relation to society, the environment, and its potential for expansion. These are generally politically correct statements, which help to develop 
management practices within the parameters that lead to sustainable development (Eletrobras, 2010; Eletrobras, 2011).

The ecological marketing, for instance, is used by companies who claim to promote a Brazilian hydroelectric management focused on environmental sustainability (Eletrobras, 2010; Eletrobras, 2011; Eletrobras, 2012); the same media entities often feature environmental disasters, environmental management practices of the hydroelectric sector that affect or will affect the construction of reservoirs or dams; one realizes that there is an unknown regarding environmental, economic, and social sustainability to be unveiled, concerning the current problem and as well as the exposed problem (Fearnside, 2013a; Fearnside, 2013b; Sühlsen \& Hisschemöller, 2014).

Presently, the guidelines are planned both within governmental, through the agreements reached in international conferences, as in the national and organizational bodies whose main purpose is to outline goals to promote studies, develop technologies, deploy legal mechanisms, and encourage projects aimed at targets in balance with nature, in accordance, moreover, with the development of the capacity of countries and regions so that they can obtain equitable social benefits, allied to the environmental balance (Rojas, 2009; United Nations Framework Convention on Climate Change [UNFCCC], 2013; Tollefson \& Gilbert, 2012; Dittmar, 2014).

Facing the above, it is important to consider the historical process of the development of hydroelectric projects in Brazil, within the context of planning the hydroelectric sector, integrating technical aspects, economic, institutional, regulatory, and control of variables involving issues related to water, land, vegetation, climate, fauna and fish fauna, population and pollution, among others.

What was said shows that it is important to consider the socio-environmental analysis to understand the vulnerability of these dimensions and thus be able to propose mechanisms for redressing and protecting of the environment. When speaking of vulnerability of the environment, it is important to highlight the existing mechanism to repair and/or protect the ecosystem (Fu et al., 2014).

Various legal mechanisms have been deployed by the government of Brazil to promote environmental sustainability. Among them, we can highlight tax incentives (tax on circulation of goods and servisos- - "ICMS Ecologico" income tax, eco credit, etc., among others), which intend to reach a trade-off, to stimulate the economy to promote sustainability, with the aim to monitor and verify the practices employed by productive sectors on the environment (Pires, 2012; Riva, Fonseca, \& Hasenclever, 2007).

Other organizationally practices adopted are tied with environmental accounting which is an environmental information tool for managers; among the various existing methods, we can highlight the multivariate indicators that contribute to carry out the evaluation's importance for the decision-making of governmental and non-governmental organizations that evaluate holistically methods to enlarge operating performance coupled with sustainable development (Tinoco \& Kraemer, 2008; Fiorini, Souza, \& Mercante, 2013; Moreira, 2013; Valerrama \& Moreno, 2012).

Therefore, the objective of this research is to carry out theoretical and conceptual reasons, from the state of the art point of view of the literature on the topic of sustainability focused on the Brazilian hydroelectric energy sector.

\section{Connection of Sustainability With the Hydroelectric Sector of Brazil}

The hydroelectric sector is currently considered as a good contribution to economic and social development for the society in the global world. This development should be analyzed within a sustainable 
structure, and in parallel, considering that its assessment should be the focus of various aspects in relation to the human actions. These actions include professional, labor, social activities, or even economic influences, resulting activities, at the regional or national levels, but they can also form de-contextualize the concept of a sustainable development (Soito, 2011; Pang, Mörtberg, \& Brown, 2014).

Large scale hydropower is a renewable energy source that is commercially viable in Brazil; its significant contribution and importance to human development is evident. Among its attributes, there is the production of negligible amounts of greenhouse gases (GHG). In the long run, the electro producer system stores large quantities of low-cost electricity that can be adjusted to meet consumer demand (Fu et al., 2014).

The first hydroelectric potentials implanted in Brazil began in the mid-nineteenth century, in 1883, where came into operation the first hydroelectric central called "Ribeirão do Inferno" located in the town of Diamantina in the state of Minas Gerais; the reasons for catching the interest on the implementation of such ventures in the country at the time, was the increase of turnover related to coffee (A. Souza, J. Souza, Oliveira, \& Estevam, 2011b; Pinto, 2012).

The electric energy entrance propitiated the magnifying of the urban demand of the city of São Paulo that when attracting investors provided to the industrial development of the country allied to the increase of the migratory process of the people of the small urban and agricultural centers for the great centers in search of work and better conditions of life (Soito, 2011).

In the early 1970s, the great environmental impacts caused by hydroelectric power plants in Brazil and in the world were a constant due to the lack of criteria for the evaluation of projects; this period was marked by the absence of government policies directed toward the social and environmental issues, and by the absence of concerns on the part of the leaders of companies that prioritized economic-financial aspects only, using natural resources indiscriminately (Soito, 2011).

Brazil is a country with a large hydro potential, which has a large population and territorial extent, factors that contribute to the growing demand for electricity coupled with the deployment of companies to work in this sector. The power generation units are responsible for $117,134,724 \mathrm{~kW}$ total installed powers to meet the energy demand of Brazil; in 2011, there were 181 hydroelectric plants that contributed to 78,371,279 kW corresponding to $91 \%$ of the production potential of the country's electricity [Agência Nacional De Energia Elétrica (National Agency of Electrical Energy) [ANEEL], 2012].

The Eletrobras Holding controls the concessionaires and the operations in the national scope of all the enterprises power related (Eletrobras, 2012), enterprises that in a general way, are supported and financed for the Banco Nacional de Desenvolvimento Econômico e Social (Brazilian Development Bank) (BNDES) [Empresa De Pesquisa Energética (Energy Research Company) [EPE], 2011; Banco Nacional De Desenvolvimento Econômico e Social (Brazilian Development Bank) [BNDES], n.d.].

The Brazilian electrical Power Plants S.A.-Eletrobras, the biggest company of the energy sector of all the Latin America countries acts directly and indirectly in the whole national territory, and it controls close to $50 \%$ of the capital, considering the Itaipu Company which is the biggest electrical power producing company in the world, with 42.302 MW of installed power production capacity (Eletrobras, 2011; Eletrobras, 2012).

The hydroelectric enterprises contribute to promote better wellbeing of the human beings when satisfying its necessities of consumption, offering one better quality of life, supplying water the urban use, generation of energy, flood irrigation, recreation, and control. Also, they cooperate in the promotion of the regional development, in the generation of employment, increasing direct electricity sales. Moreover, they contribute to 
ensure the energetic independence of Brazil, amongst other attributes that evidence the societal dependence of the Brazilian economy.

\section{Review of Literature Itself: The State of the Art}

Some recent contributions allow further with a quick review of the state of the art on the social and environmental impacts of hydropower, also addresses the theme mechanisms to promote economic, social, and environmental sustainability under the topic of sustainability published in international journals important in the world.

\section{Social and Environmental Impacts of Hydroelectric}

This section presents some recent contributions that serve to complement a quick review of the state of the art on the socioeconomic impacts of environmental hydropower recently published in international journals of the world; it also addresses the issue of mechanisms to promote the three pillars of sustainability - economic, social, and environmental.

Environmental impacts of hydropower plants - the hydroelectric plants tend to flood and eliminate large extensions of cultivable land such as land to pasture, as well as areas with poor nutritional status whose resources may be essential to sustain millions of human's beings, women, men, children, elderly, among others (Sharma \& Rana, 2014; Polimeni, Iorgulescu, \& Chandrasekara, 2014).

The processes of new colonizing generates loss of material wealth and immaterial society, in general, are inadequate because they tend to have not enough water to meet all the people's needs, therefore, generally lead to later negative results, such as the proliferation of cholera and other water related diseases or before its lack (T. Santos, L. Santos, Albuquerque, \& Corrêa, 2012; Wang, Wolf, Lassoie, \& Dong, 2013).

Several families displaced and resettled that those live in the vicinity of a reservoir may lose access to the water of the river and the natural wells, for various reasons, as though living in the vicinity of areas of hydroelectric plants means to have a network of supply itself (Nascimento \& Silva, 2011).

The families are affected by the lack of treated (good) water which leads to supply water unfit for consumption, the effects of a planning for the transfer of water that is not revitalized from another basin but that is not suitable for human consumption or for entrepreneurial activities such as livestock (cattle) and irrigation, among others (Polimeni et al., 2014).

As an example, we may refer the cases of some villages and riverside communities in the Amazon region in Brazil that still need treated water, electric light, and proper medical care to support their economic and financial development processes; in fact, despite all the technological, social, and economic development lived there are several regions and communities of Brazil, there are still living in sub-human conditions (Polimeni et al., 2014; Silva, 2012).

The environmental impacts generated by a hydroelectric dam may occur upstream and downstream. As said by World Commission on Dams (WCD) (2000) and Finotti, Cemin, and Périco (2011), the impacts can be classified into three classes - impacts of first order or direct, impacts of second order, and impacts of third order, impacts that arise in different ways.

Changes in Thermal Regime: The temperature regulates the physical, chemical, and biological processes; likewise, the water reservoirs of hydroelectric ventures act as thermal regulators to allow only small changes in temperature between seasonal periods. The water to be retained in the reservoir tends to increase its 
temperature and acquires a new standard of thermal behavior, depending on the geographic location; the water stored in deep reservoirs tends to be thermally stratified (McCartney, Sullivan, \& Acreman, 2001; Fleming \& Weber, 2012; Lee, Chung, Ryu, \& Choi, 2013; Ferreira \& Cunha, 2013; Gebre, Boissy, \& Alfredsen, 2014).

Thermal changes tend to form three types of layers. One with the higher temperature and thoroughly mixed which is in contact with the surface, with features intermediate between the two extremes, and a bottom with the lowest temperature and less density (Fleming \& Weber, 2012; Lee et al., 2013; Umaña-Villalobos, 2014; Gebre et al., 2014). Some methods are applied to eliminate or reduce this stratification of shells, as the cooling method of reservoir, the axial flow pumps, the mechanical mixer, the pneumatic aeration diffuser - which consists of reducing the level of the reservoir to a limit that allows circulation and mixing a large amount of water flow that allowing the elimination of stratification (Bedri, Bruen, Dowley, \& Masterson, 2013; Frota et al., 2014; Liu, 2014).

Impacts by sedimentation. The excess sedimentation eventually can annul the tank capacity from fulfilling the tasks or functions for which it was established, as for example, irrigation, flood control, and electric power generation. In addition, it can also cause environmental degradation, damage the equipment, input structures, and turbines, and still cause impacts linked to the presence of polluting sediments (Souza, Medeiros, Brandini, \& Knoppers, 2011a; Lana \& Castro, 2011; Arias et al., 2014). The basins of the dams of hydroelectric power stations in general are affected with high levels of sedimentation (Okawa, 2010; Arias et al., 2014); in the case of a typical sedimentation, it is considered to affect the reservoir after 50 years of use of hydropower, although in certain reservoirs, after 10 years of use, it suffers the process of sedimentation (Bishwakarma, 2007).

According to WCD (2000) and International Commission On Large Dams (ICOLD) (n.d.), to solve the problems related to the erosion of the banks of a river, it is used a technology known as "piping", so named for the resemblance to the tubular cavity generated; this process corresponds to using a powerful erosive agent that changes the main channel of the river and the secondary channels.

In storage volume recovery, the technique may be used to remove the sediments deposited, combined with the reduction at the level of the reservoir, through the utilization of siphons, excavators, especially the excavation by suction, and the application of analytical methodologies that use hydrodynamic models (ICOLD, n.d.; Bishwakarma, 2007; Luis, Sidek, Desa, \& Julien, 2013; Arias et al., 2014). These methodologies were allow to take advantage of the energy charge that exists between the surface of the reservoir and the output shaft for removal of sediment inside the tank, thus nullifying the need for an external source of power, which can also vary depending on the diameter and length of pipes (Bishwakarma, 2007). These techniques have been employed successfully in hydroelectric potentials of Nepal, for example, by given companies such as "GTO Sediment AS"- using SPSS (Statistical Package for the Social Sciences) methods and SSS (Saxophone Sediment Sluice) - and by the Hydrotechnical Laboratory of Norway known as "SINTEF NHL" that also uses these methodologies (Bishwakarma, 2007).

Impacts by the proliferation of plankton ${ }^{1}$. In general, the production systems of phytoplankton are moderate, varying with the algal communities inside the river basins, the types of lakes, the speeds of water; the

\footnotetext{
${ }^{1}$ Plankton refers to a small community of microorganisms that live in free waters (pelagios), which presents limitations in terms of locomotion, enabling their limited or permanent fluctuation; their displacement comes from water movements; is the food chain of aquatic ecosystems and also serves as food for larger organisms. Generally, the plankton is subdivided into three types: phytoplankton (formed mainly by microscopic algae); ick-plankton (formed by larval or juvenile forms of nekton in low movement motion); and zoo-plankton (formed by animals) (Miranda \& Gomes, 2013).
} 
production of plankton is unstable and dependent on the frequency of high discharges (Netto, 2011; Bottino, 2012; Umaña-Villalobos, 2014). The proliferation of plankton in the reservoirs accelerates the production of these living beings - plants or animals both upstream and downstream the river. The process of decomposition of the substance becomes anaerobic; thus, carbon dioxide, methane, and hydrogen are released, the $\mathrm{pH}$ of water decreases and within the basin or reservoir there occur, since the sediment, the reactions of iron and manganese; the nutrients, including the phosphorus, are released biologically and leachate by the vegetation and soil submerged (ANEEL, 2000; Tavera \& Novelo, 2011; Netto, 2011). The proliferation of plankton starts with the closure of water outlets to be able to fill the reservoir; the system is slow and therefore accelerates the production of this plant and at the same time that occurs the accelerated increase of microbes, some nutrients are released from organic matter flooded, providing an incentive for parallel development of phytoplankton to take advantage of the solar energy. Damming a river, in addition to modifying the hydraulic conditions, also provides changes in parallel processes of phytoplankton and the biomass constitution (Umaña-Villalobos, 2014).

In the reservoir of the Three Gorges in China, although the flow velocity limits the growth of a given organic production, due to high $\mathrm{pH}$ (above 8) of the Yangtze River, the phosphorus from the water was transformed into insoluble compound, to combine with fine sediments which in great part is removed with the discharges, thus, the concentrations of soluble phosphorus which are consumed by the algae are replaced by a low level on the reservoir that does not promote the accumulation of nutrients; for this reason, eutrophication within the reservoir of hydropower exploitation should not occur (Fu et al., 2010; Xu, Tan, Yang, Li, \& Su, 2011; Xu, Tan, \& Yang, 2013a; Xu et al., 2013b).

However, on the shores of the basin or sump, where the flow velocity decreases, phytoplankton can grow, and the production of eutrophication occurs. To avoid such problems, it is essential to have a control over the sump area of the hydroelectric power plant (Fu et al., 2010; Xu et al., 2011; Xu et al., 2013a; Xu et al., 2013b).

Over the years, the levels of nutrients and organic matter tend to decrease, and may reach the schemes of stability of water from 20 years. After this stage of maturation of the shell, the same may serve as reservoir of nutrients, identical to natural lakes, especially with nutrients bound to the sediments. The process of eutrophication of reservoirs can generate great influence of organic matter and nutrients (Umaña-Villalobos, 2014).

Impacts of periphyton ${ }^{2}$. Periphyton usually is formed upstream of the dam or reservoir or central basin hydropower, in layer of algae unified in material that is submerged; it can be objects or plants. The development of the site periphyton is one in which there is sunlight that penetrates the water, especially near the margin of the reservoir (Rodrigues \& Hayashi, 2013; Mascarenhas, 2013; Smolar-Žvanuta \& Mikošb, 2013). The nature of the substrate is determined by the type of kind, coupled with the presence or absence of aquatic macrophytes, to chemical reactions and temperature, which occur in the water, and operating procedures of the reservoir of the hydroelectric utilization; these elements are added to determine the characteristics of periphytons (Tavera \& Novelo, 2011; Mascarenhas, 2013; Smolar-Žvanuta \& Mikošb, 2013).

\footnotetext{
2 "The periphyton is represented by a thin layer (biofilm) ranging in a few millimeters, which operates at the interface between the substrate and the surrounding water, are observed as green spots or brown is clinging to submerged in water objects such as rocks, logs, artificial objects (inert), and aquatic vegetation. Periphyton is defined as a complex microorganisms community (algae, bacteria, fungi, animals), organic and inorganic detritus that is attached to dead or living, organic or inorganic substrata. It is constituted as an important food for the trophic chains. Importance, perifitica community structure and dynamics in aquatic ecosystems". Retrieved from http://www.ib.usp.br/limnologia/Perspectivas/arquivo\%20pdf/Capitulo\%206.pdf, consulted on April 16, 2014.
} 
Downstream, the periphyton grows in abundance near the reservoir, due to large sediment discharges, or where the slope of the canal and river speeds are smaller; but in areas downstream of the dam, they are limited by the reduction of the entrance of light, associated with the high content of suspended sediments, increasing concentrations of organic matter, and by the maters' depth (Mascarenhas, 2013; Tavera \& Novelo, 2011).

Impacts of macrophytes. The presence of aquatic macrophytes is associated with degrading processes of environment contamination inducers and pollution of water in the reservoirs, which alters the natural quality of the water and compromises the quality of aquatic life (Gómez, Pérez-Blanco, \& Batalla, 2013; Chappuis, Gacia, \& Ballesteros, 2014). Generally speaking, the reforestation of the area around the reservoir contributes to reduce sedimentation and to improve environmental quality. Changes in reservoir water levels can affect the vegetations that are around the reservoir. Downstream of the hydroelectric utilization, the macrofitas possess characteristics of riverside communities. Some riparian plant species require aquifers in the plains of floods, which are transported during periods of flooding (Bergkamp, McCartney, Dugan, Mcneely, \& Acreman, 2000; Okawa, 2010; Souza et al., 2011a).

Mechanisms to promote economic, social, and environmental sustainability. Repair of environmental damage caused by human intervention is a mechanism on the motivation that includes some important tools for the sustainable development as are the cases of the polluter-payer principle (Luppi, Parisi, \& Rajagopalan, 2012; Munir, 2013; Brandt \& Svendsen, 2014), the principle of protective recipient (Ribas, 2013; De-Paulo, 2013), the trade-off or "compensatory exchange" (Meensel, Lauwers, Huylenbroeck, \& Passel, 2010; J. Zhang, M. Fu, Z. Zhang, Tao, \& W. Fu, 2014; Blandford, Gaasland, \& Vårdal, 2014; Akter, Graftonb, \& Merritt, 2014) and the tax incentives, among others (Nesta, Vona, \& Nicolli, 2014; Martinez-Espiñeira, García-Valiñas, \& Nauges, 2014; Allan, Lecca, Mcgregor, \& Swales, 2014). Other motivational mechanisms include some programs that operate as incentives, for example, taking the cable to repair environment from the obtaintion of some benefits, such as the Ecological ICMS or Tax on the Circulation of Goods and Services and the Go-Green or Income Tax, in order to benefit companies responsible and committed, not only with the preservation and maintenance, but also with the repair of the Brazilian environment (Riva et al., 2007; De-Paula, 2013). Over the decades of 80s and 90 s of the last century, various public policies designed for the environment, originated various proposals for implementation with the aim of preserving the environmental areas. However, the enforcement has been problematic and the pace of deforestation has not decreased consistently or as it should (Paula, 2011).

Business awareness. Puaschunder (2012) in a study about the socially responsible investments in both qualitative and quantitative analysis on the financial market allied to social and environmental impacts, came to the conclusion that we should employ the corporate social responsibility (CSR) in planning and decisions. The non-application or the application of a limited form of financial responsibility coupled with social one can be regarded as irresponsible management in decision-making (Puaschunder, 2012; Tayşir \& Pazarcık, 2013; Avram \& Avasilcai, 2014; Kahreh, Babania, Tive, \& Mirmehdi, 2014). The exchange of financial profits through mechanisms of repair in favor of bonuses, is a good technique to achieve the environmental objectives predefined because it can help these companies to expand their awareness and organization and simultaneously can develop appropriate procedures to cover the expansion of their profits and at the same time can contribute to the resolution of the socio-environmental issues (Blandford et al., 2014; Akter et al., 2014). The social and environmental repair mechanisms encourage the decision-makers to develop a responsible and compromised attitude and, in addition to contributing to a social and environmental education in organizational framework so that the procedures are planned and executed in a conscious and adequate manner (Fu et al., 2014). 
In Brazil, the high incidence of environmental damage incurred as a result of actions that generate pollution (noise, atmospheric visual, irregular buildings, use and occupation of land in disagreement with the rules, generating environmental impact through the occupation of green areas, the deposition of manure, solid waste and toxic in water resources, among others, that directly affect the society quality of life (Hammer, Swinburn, \& Neitzel, 2014; Garí, Bosch, Grimalt, \& Sunyer, 2014; Wagtendonk \& Vermaat, 2014; Paulino, 2014; Souza, Miziara, \& Junior, 2013; He, Zhang, Mol, Wang, \& Lu, 2014; Quina, Bordado, \& Quinta-Ferreira, 2014). Such occurrences are expressed in national and global context that produce economic inequality continuously, as a result of the appropriations increasing natural resources, requiring more effective and immediate environmental justice. For these issues, it is important to question if the profit overrides the legal sanction imposed on offenders, as the value of the fine enforcement or punishment is applied before the importance of the dimension of enterprise or volume of business involved, the criminal coercion represents a negligible value in face of the volume of business obtained, or if it is worth breaking the law and pay the amounts stipulated by justice (Motta, 2006; Uhlmann, 2011; Souza et al., 2013). This is a question to be considered to understand the lack of environmental awareness on the part of the decision-makers as well as the overlap of the capital on the resources of nature and respect for the environment (Motta, 2006; Uhlmann, 2011; Djekic \& Smigic, 2013; Souza et al., 2013).

The hydroelectric companies declare increasingly accountable to society, all their procedures and management strategies that can be verified through a management mechanism called "Eco-Marketing" exposed mainly through the sustainability reports Hydroelectric companies declare increasingly accountable to society, all its procedures and management strategies that can be verified through a management mechanism called "Eco-Marketing" exposed, primarily through the sustainability reports of the holding company Eletrobras (Koenig-Lewis et al., 2014; Mariadoss et al., 2011). Until a few decades ago, the manager had the obligation to publish the economic balance, however, currently, the governmental bodies are increasingly demanding with regard to the requirements in terms of sustainable management practices that affect the economic, social, and environmental dimensions (Wiengarten et al., 2013; Djekic \& Smigic, 2013), which are subsequently declared through the Sustainability Reports drawn up on the basis of the model of the Brazilian Institute of Social and Economic Analyses (Instituto Brasileiro de Análises Sociais e Econômicas) (IBASE) (Correa, 2012; Perego \& Kolk, 2012).

\section{Conclusions}

This study aims to assess the strengths, medium, and weaknesses in economic, environmental, and social dimensions to be able to implement or adapt actions to promote the sustainable development of Brazil's hydraulic power production sector. To properly appraise the sustainability, it is necessary to comprehensively examine the whole, having in view that the environmental management system is the basis, despite the interconnection of social systems and economic. For this reason to occur the balance, i.e., the sustainability, it is necessary to change some of the ethical, behavioral issues and especially the decisions of people who have the responsibility to promote social equity and justice. The greatest difficulty to assess the sustainable development of hydro in Brazil is to identify an appropriate way to construct plants and produce hydroelectric power that minimize social, economic, and environmental impacts.

Although there are other sources of energy less aggressive to the environment, which makes it more independent in terms of energy, in this country, it is precisely the great quantity of available water resources, 
inputs of a source of energy also considered renewable, cheap, and not so pollutant, when compared with other existing sources of energy. The hydroelectric power at the same time affecting the conservation of natural resources and the social environment, also provide a quality of life increased by the society and expand the control of natural resources through the implementation of projects that are designed to minimize its impact and effectively contribute to the expansion of the economy of the country.

The paper concludes that Brazil and the Holding Eletrobras have mechanisms to foster appropriate procedures that have to put the guidelines, the legislation, and the methods into practice, finally, all the existing tools that may arise, tools that will contribute to the promotion of sustainability in Brazil and the hydropower industry; it is shown that the major socio environmental impacts prevail over the interests of the minority (the economic sector) to the profit on the fundamental interests that protect it against the survival of life on earth.

\section{References}

Agencia Nacional de Energia Elétrica (National Agency of Electrical Energy)—ANEEL. (2000). Guia de Avaliação de Assoreamento de Reservatórios. Superintendência de Estudos e Informações Hidrológicas (Guide reservoir sedimentation assessment. Superintendent of studies and hydrological information). Retrieved from http://www.aneel.gov.br/biblioteca/ downloads/livros/Guia_ava_port.pdf

Agência Nacional de Energia Elétrica (National Agency of Electrical Energy)—ANEEL. (2012). Report 2011. Publishing House ANEEL National Agency of Electrical Energy, Brasília.

Akter, S., Graftonb, R. Q., \& Merritt, W. S. (2014). Integrated hydro-ecological and economic modeling of environmental flows: Macquarie Marshes, Australia. Agricultural Water Management, 145, 98-109.

Alexander, S., \& Rutherford, J. (2014). Debating strategies of transition. Simplicity Institute Report, 11(1), 25.

Allan, G., Lecca, P., Mcgregor, P., \& Swales, K. (2014). The economic and environmental impact of a carbon tax for Scotland: A computable general equilibrium analysis. Ecological Economics, 100, 40-50.

Alves, J., \& Júnior, A. T. (2011). A degradação do Trabalho no "complexo hidrelétrico madeira": apontamentos sobre a UHE de Jirau (Degradation of work in the "wood hydroelectric complex": Notes on the UHE Jirau). Journal Footprint, 12 (2), 9.

Arias, M. E., Cochrane, T. A., Kummu, M., Lauri, H., Holtgrieve, G. W., Koponen, J., \& Piman, T. (2014). Impacts of hydropower and climate change on drivers of ecological productivity of Southeast Asia's most important wetland. Ecological Modelling, 272, 252-263.

Avram, E., \& Avasilcai, S. (2014). Business performance measurement in relation to corporate social responsibility: A conceptual model development. Procedia-Social and Behavioral Sciences, 109, 1142-1146.

Banco Nacional De Desenvolvimento Econômico e Social-BNDES (Brazilian Development Bank). (n.d.). Retrieved from http://www.bndes.gov.br/SiteBNDES/bndes/bndes_pt/Institucional/Apoio_Financeiro/

Barbosa, L., \& Veloso, L. (2014). Consumption, domestic life and sustainability in Brasil. Journal of Cleaner Production, 63, 166-172.

Bedri, Z., Bruen, M., Dowley, A., \& Masterson, B. (2013). Environmental consequences of a power plant shut-down: A three-dimensional water quality model of Dublin Bay. Marine Pollution Bulletin, 71(1-2), 117-128.

Bergkamp, G., McCartney, M., Dugan, P., Mcneely, J., \& Acreman, M. (2000). Dams, ecosystems, functions and environmental restorations. WCD Thematic Review Environmental Issues, 2(1), 199. Retrieved from http://intranet.iucn.org/webfiles/ doc/archive/2001/IUCN913.pdf

Bishwakarma, M. B. (2007). Addressing sediment problems. International Water Power \& Dam Construction. Retrieved from http://www.waterpowermagazine.com/features/featureaddressing-sediment-problems/

Blandford, D., Gaasland, I., \& Vårdal, E. (2014). The trade-off between food production and greenhouse gas mitigation in Norwegian agriculture. Agriculture, Ecosystems \& Environment, 184, 59-66.

Brandt, U. S., \& Svendsen, G. T. (2014). A Global CO2 Tax for sustainable development? Journal of Sustainable Development, 7(1).

Chappuis, E., Gacia, E., \& Ballesteros, E. (2014). Environmental factors explaining the distribution and diversity of vascular aquatic macrophytes in a highly heterogeneous Mediterranean region. Aquatic Botany, 113, 72-82.

Corrêa, R. (2012). Evolução dos Níveis de Aplicação de Relatórios de Sustentabilidade (GRI) de Empresas do ISE/Bovespa [Evolution of sustainability reporting application levels (GRI) of the ISE/Bovespa companies]. Sociedade, Contabilidade e Gestão, Rio de Janeiro (Society, Accounting and Management, Rio de Janeiro), 7(2), 24-40. 
De-Paula, M. F. (2013). Ecological ICMS and Indian lands: A study in the case of Marrecas-PR's Indian lands. Capital Cientifico (Scientific Capital), 11(1), 1-16.

De-Paulo, F. L. L. (2013). Imposto sobre circulação de mercadorias e serviços_ICMS socioambiental: Avaliação da política do Estado de Pernambuco nos últimos cinco anos na perspectiva da gestão ambiental (Tax on movement of goods and services, environmental ICMS: State of Pernambuco Policy Evaluation in the last five years in the context of environmental management). IX Fórum Ambiental da Alta Paulista (IX Environmental Forum Alta Paulista), 9(5), 47-65.

Dittmar, M. (2014). Development towards sustainability: How to judge past and proposed policies? Half of the Total Environment Sciences, 472, 282-288.

Djekic, I., \& Smigic, N. (2013). Environmental issues revealed in certified bottling companies in the Republic of Serbia. Journal of Cleaner Production, 41, 263-269.

Eletrobras. (2010). Relatório de Sustentabilidade, 2010 (Sustainability Report, 2010). Retrieved from http://www.eletrobras.com/ elb/main.asp?Team=\%7B4A2B5B3C-751A-4E38-86A7-D6085CEE347B\%7D\#2010

Eletrobras. (2011). Relatório de Sustentabilidade, 2011 (Sustainability Report, 2011). Retrieved from http://www.eletrobras.com/ elb/main.asp?Team=\%7B4A2B5B3C-751A-4E38-86A7-D6085CEE347B\%7D\#2011

Eletrobras. (2012). Relatório Anual de Sustentabilidade (Sustainability Annual Report). Retrieved from http://www.eletrobras. com/relatorio_sustentabilidade_2012/

Empresa de Pesquisa Energética (Energy Research Company)_EPE. (2011). Brazilian energy balance 2011, year 2010/Energy research company. Rio de Janeiro: Publishing House EPE.

Fang, Y., \& Deng, W. (2011). The critical scale and section management of cascade hydropower exploitation in Southwestern China. Retrieved from http://dx.doi.org/10.1016/j.energy.2011.08.022

Fearnside, P. M. (2013a). Impacts of Brazil's Madeira River Dams: Unlearned lessons for hydroelectric development in Amazonia. Environmental Science \& Policy, 38, 164-172.

Fearnside, P. M. (2013b). Análisis de los principales proyectos hidro-energéticos en la región amazónica (Analysis of the main hydro-energy projects in the Amazon region). Retrieved from http://webcache.googleusercontent.com/ search? $\mathrm{q}=$ cache: KNTOg4VBBA0J:philip.inpa.gov.br/publ_livres/Preprints/2013/Fearnside-AN\%25C3\%2581LISIS-Hidroelectricas-Preprint. $\mathrm{pdf}+\& \mathrm{~cd}=2 \& \mathrm{hl}=\mathrm{pt}-\mathrm{BR} \& \mathrm{ct}=\mathrm{clnk} \& \mathrm{gl}=\mathrm{pt}$

Ferreira, D. M., \& Cunha, C. (2013). Simulação numérica do comportamento térmico do reservatório do Rio Verde (Numerical simulation of the thermal behavior of the Green River reservoir). Sanitary and Environmental Engineering, 18(1), 83-93.

Finotti, A. R., Cemin, G., \& Périco, E. (2011). Potential use of remote sensing and geographic information systems (GIS) in hydrology teaching: The use of a case study. Revista Geografia-Londrina, 20(1), 51-65.

Fiorini, A. J. C. E., Souza, C. C., \& Mercante, M. A. (2013). A Pegada Ecológica como Instrumento de Avaliação Ambiental da Cidade de Campo (The ecological footprint and environmental assessment tool field city). Sustentabilidade em Debate (Sustainability Debate), 4(1), 231-248.

Fleming, S. W., \& Weber, F. A. (2012). Detection of long-term change in hydroelectric reservoir inflows: Bridging theory and practice. Journal of Hydrology, 470-471, 36-54.

Frota, M. N., Ticona, E. M., Neves, A. V., Marques, R. P., Braga, S. L., \& Valente, G. (2014). On-line cleaning technique for mitigation of biofouling in heat exchangers: A case study of a hydroelectric power plant in Brazil. Experimental Thermal and Fluid Science, 53, 197-206.

Fu, B., Wang, Y. K., Xu, P., Yan, K., \& Li, M. (2014). Value of ecosystem hydropower service and its impact on the payment for ecosystem services. Science of the Total Environment, 472, 338-346.

Fu, B.-J., Wu, B.-F., Lu, Y.-H., Xu, Z.-H., Cao, J.-H., Niu, D., ... Zhou, Y.-M. (2010). Three Gorges Project: Efforts and challenges for the environment. Progress in Physical Geography, 34(6), 741-754.

Garí, M., Bosch, C., Grimalt, J. O., \& Sunyer, J. (2014). Impacts of atmospheric chlor-alkali factory emissions in surrounding populations. Environment International, 65, 1-8.

Gebre, S., Boissy, T., \& Alfredsen, K. (2014). Sensitivity to climate change of the thermal structure and ice cover regime of three hydropower reservoirs. Journal of Hydrology, 510, 208-227.

Golini, R., Longoni, A., \& Cagliano, R. (2014). Developing sustainability in global manufacturing networks: The role of site competence on sustainability performance. International Journal of Production Economics, 147(Part B), 448-459.

Gómez, C. M., Pérez-Blanco, C. D., \& Batalla, R. J. (2013). Tradeoffs in river restoration: Flushing flows vs. hydropower generation in the Lower Ebro River, Spain. Journal of Hydrology, 518(Part A), 130-139. 
Hammer, M. S., Swinburn, T. K., \& Neitzel, R. L. (2014). Environmental noise pollution in the United States: Developing an effective public health response. Environmental Health Perspectives, 122(2), 5. Retrieved from http://dx.doi.org/10.1289/ ehp.1307272

He, G., Zhang, L., Mol, A. P. J., Wang, T., \& Lu, Y. (2014). Why small and medium chemical companies continue to pose severe environmental risks in rural China. Environmental Pollution, 185, 158-167.

Heinimann, R. H. (2010). A concept in adaptive ecosystem management-An engineering perspective. Forest Ecology and Management, 259(4), 848-856.

International Commission on Large Dams-ICOLD. (n.d.). Technology of dams. Retrieved from http://www.icold-cigb. net/search_result.asp

Kahreh, M. S., Babania, A., Tive, M., \& Mirmehdi, S. M. (2014). An examination to effects of gender differences on the corporate social responsibility (CSR). Procedia-Social and Behavioral Sciences, 109, 664-668.

Koenig-Lewis, N., Palmer, A., Dermody, J., \& Urbye, A. (2014). Consumers' evaluations of ecological packaging-Rational and emotional approaches. Journal of Environmental Psychology, 37, 94-105.

Lana, C. E., \& Castro, P. T. A. (2011). A influência da geodiversidade da região da Serra do Cabral (norte de MG) na variabilidade morfossedimentar do Córrego da Gameleira [The influence of geo-diversity of the Serra do Cabral region (north of Minas Gerais) in morfossedimentar variability Stream of Gameleira]. Revista Brasileira de Geociência (Journal of Geoscience), 41(4), 504-618.

Lee, H., Chung, S., Ryu, I., \& Choi, J. (2013). Three-dimensional modeling of thermal stratification of a deep and dendritic reservoir using ELCOM model. Journal of Hydro-Environment Research, 7(2), 124-133.

Liu, J., Zuo, J., Sun, Z., Zillante, G., \& Chen, X. (2013). Sustainability in hydropower development—A case study. Renewable and Sustainable Energy Reviews, 19, 230-237.

Liu, T. (2014). Modelling air-Water flows in bottom outlets of dams. Retrieved from http://www.diva-portal.org/smash/get/ diva2:695501/FULLTEXT01.pdf

Luis, J., Sidek, L. M., Desa, M. N. M., \& Julien, P. Y. (2013). Sustainability of hydropower as source of renewable and clean energy. IOP Conference Series: Earth and Environmental Science, 16(Conference 1). Retrieved from http://iopscience.iop. org/1755-1315/16/1/012050/pdf/1755-1315_16_1_012050.pdf

Luppi, B., Parisi, F., \& Rajagopalan, S. (2012). The rise and fall of the polluter-pays principle in developing countries. International Review of Law and Economics, 32(1), 135-144.

Mariadoss, B. J., Tansuhaj, P. S., \& Mouri, N. (2011). Marketing capabilities and innovation-based strategies for environmental sustainability: An exploratory investigation of B2B firms. Industrial Marketing Management, 40(8), 1305-1318.

Martínez-Espiñeira, R., García-Valiñas, M. A., \& Nauges, C. (2014). Households' pro-environmental habits and investments in water and energy consumption: Determinants and relationships. Journal of Environmental Management, 133, 174-183.

Mascarenhas, G. L. (2013). Caracterização do fitoplâncton das bacias do rio São Francisco, Moxotó e Paraíba, inseridas no projeto de integração do rio São Francisco (Phytoplankton characterization of river basins San Francisco, Moxotó and Paraíba, inserted in the São Francisco river integration project). Revista Brasileira de Geografia Física, 6(5), 1050-1068.

Matthew, B. C., \& Nigel, W. A. (2011). Adapting to climate change impacts on water resources in England—An assessment of draft water resources management plans. Global Environmental Change, 21(1), 238-248.

McCartney, M. P., Sullivan, C., \& Acreman, M. C. (2001). Ecosystem impacts of large dams. Retrieved from http://www. dams.org/kbase/thematic/

Medina, J. J. (2013). La construcción histórica del principio de precaución como respuesta al desarrollo científico y tecnológico (The historic building of the precautionary principle in response to scientific and technological development). Dilemata, 11, 1-19.

Meensel, J. V., Lauwers, L., Huylenbroeck, G. V., \& Passel, S. V. (2010). Comparing frontier methods for economic-Environmental trade-off analysis. European Journal of Operational Research, 207(2), 1027-1040.

Miranda, V. B. S., \& Gomes, E. A. T. (2013). Alterações na comunidade zooplanctônica do rio taquara (duque de caxias, rj), resultantes do lançamento de efluentes industriais e domésticos [Changes in the zooplankton community of the river cane (caxias Duke, rj), resulting from the disposal of industrial effluents and domestic]. Retrieved from http://publicacoes.unigranrio.br/index.php/sare/article/viewFile/2007/1069

Moreira, S. B. (2013). Sobre a medição da componente ambiental do desenvolvimento: principais abordagens e indicadores (On the measurement of the environmental component of development: Main approaches and indicators). Desenvolvimento $e$ Meio Ambiente (Development and Environment), 27, 121-132.

Motta, R. S. (2006). Analyzing the environmental performance of the Brazilian industrial sector. Ecological Economics, 57(2), 269-281. 
Munir, M. (2013). History and development of the polluter pays principle: An overview. Department of Law, International Islamic University, Pakistan. Retrieved from http://dx.doi.org/10.2139/ssrn.2322485

Nesta, L., Vona, F., \& Nicolli, F. (2014). Environmental policies, competition and innovation in renewable energy. Journal of Environmental Economics and Management, 67(3), 396-411.

Netto, O. S. M. (2011). Control of fouling invading organisms in cooling systems of power plants material. Master's dissertation in the engineering and materials science. Undergraduate Postgraduate Program in Engineering and Materials Science-PIP. Federal University of Parana.

Okawa, C. M. P. (2010). Analysis of environmental juridical framework for Clean Development Mechanism projects (CDM) applied to the development of renewable energy. Revista Tecnológica Maringá, 19, 67-74.

Pang, X., Mörtberg, U., \& Brown, N. (2014). Energy models from a strategic environmental assessment perspective in an EU context-What is missing concerning renewables? Renewable and Sustainable Energy Reviews, 33, 353-362.

Pascual, U., Garmendia, E., Phelps, J., \& Ojea, E. (2013). Leveraging global climate finance for sustainable forests: Opportunities and conditions for successful foreign aid to the forestry sector. WIDER Working Paper. Retrieved from http://www.researchgate.net/profile/Unai_Pascual/publication/260390636_Leveraging_global_climate_finance_for_sustaina ble_forests_Opportunities_and_conditions_for_successful_foreign_aid_to_the_forestry_sector/links/0_eec5311 $599380 \mathrm{bdc} 00$ 0000.pdf?origin=publication_detail

Paula, L. N. (2011). Analysis of environmental juridical framework for Clean Development Mechanism projects (CDM) applied to the development of renewable energy. Energy Law in Brazil, 4(2), 1-23.

Paulino, E. T. (2014). The agricultural, environmental and socio-political repercussions of Brazil's land governance system. Land Use Policy, 36, 134-144.

Perego, P., \& Kolk, A. (2012). Prestação de contas das multinacionais sobre Sustentabilidade: A Evolução da Garantia de terceiros de Relatórios de Sustentabilidade (Provision of multinational accounts on sustainability: The evolution of sustainability reporting third guarantee). Journal of Business Ethics, 110(2), 173-190.

Pereira, S. (2011). Ecologismo Radical em Portugal? A "ANIMAL" e a "Quercus" (Radical ecologism in Portugal? The "ANIMAL" and "Quercus"). Retrieved from https://www.repository.utl.pt/bitstream/10400.5/3405/3/3-Disserta\% C3\%A7\%C3\%A3o.pdf

Pinto, L. C. (2012). Os projetos hidrelétricos como causa dos deslocamentos populacionais: migrações forçadas em nome do desenvolvimento (The hydroelectric projects as the cause of population displacement: Forced migrations in the name of development). Disssetação de Mestrado em Ciência Política e relações Internacionais (Master dissertation in political science and international relations). Portugal: New University of Lisbon.

Pires, P. T. L. (2012). A influência do imposto territorial rural sobre a atividade florestal (The influence of rural land tax on forestry). Master's dissertation. Graduate course in forestry, Sector of Agricultural Sciences, Federal University of Paraná. Retrieved from http://dspace.c3sl.ufpr.br:8080//dspace/handle/1884/26644

Polimeni, J. M., Iorgulescu, R. I., \& Chandrasekara, R. (2014). Trans-border public health vulnerability and hydroelectric projects: The case of Yali Falls Dam. Ecological Economics, 98, 81-89.

Puaschunder, J. M. (2012). Socio-psychological motives of socially responsible investors. Retrieved from http://papers.ssrn.com/ sol3/papers.cfm?abstract_id=1977714

Quina, M. J., Bordado, J. M., \& Quinta-Ferreira, R. M. (2014). Recycling of air pollution control residues from municipal solid waste incineration into lightweight aggregates. Waste Management, 34(2), 430-438.

Ribas, L. C. (2013). Políticas Públicas e o meio ambiente: o desafio da avaliação e monitoramento (Public policies and the environment: The challenge of evaluation and monitoring). IX Fórum Ambiental da Alta Paulista (IX Alta Paulista Environmental Forum), 9(5), 206-215.

Ribeiro, P. (2006). Lei do Ecocrédito traz benefícios para o produtor rural (Ecocrédito law has benefits for farmers). Retrieved from http://www.riodoce.cbh.gov.br/noticias/Not3_18_08_2006.asp

Rigby, M., Prinn, R. G., O’Doherty, S., Montzka, S. A., Mcculloch, A., Harth, C. M., ... Fraser, P. J. (2013). CFC and CH3CCl3 lifetimes: Re-evaluation of the lifetimes of the major $\mathrm{CFCs}$ and $\mathrm{CH} 3 \mathrm{CCl} 3$ using atmospheric trends. Published by Copernicus Publications on behalf of the European Geosciences Union. Atmos. Chem. Phys., 13, 2691-2702.

Riva, A. L. M., Fonseca, F. L., \& Hasenclever, L. (2007). Instrumentos Econômicos e Financeiros para a Conservação Ambiental no Brasil: Uma análise do estado da arte no Brasil e no Mato Grosso (Economic and financial instruments for environmental conservation in Brazil: An analysis of the state of the art in Brazil and Mato Grosso). Challenges and Prospects, Socio-Environmental Institute. Retrieved from http://www.socioambiental.org/ banco_imagens/pdfs/10295.pdf 
Rodrigues, R. C., \& Hayashi, C. (2013). Desenvolvimento de perifíton em tanques experimentais, submetidos a diferentes adubações orgânicas (Periphyton development in experimental tanks, submitted to different organic fertilizer). $A N A P-I X$ Fórum Ambiental da Alta Paulista (ANAP-IX Alta Paulista Environmental Forum), 9(3), 54-68.

Rojas, H. W. (2009). Climate change mitigation and economic development versus Asian focus against the Copenhagen Conference. OASIS-Observatorio de Análisis de los Sistemas Internacionales (OASIS-Monitoring Analysis Systems International), 14, 37-52.

Santos, T., Santos, L., Albuquerque, R., \& Corrêa, E. (2012). Belo Monte: Social, environmental, economic and policy implications. Revista de la Facultad de Ciencias Económicas y Administrativas. Universidad de Nariño (Journal of the Faculty of Economics and Administrative Sciences. University of Nariño), 13(2), 214-227.

Schrettle, S., Hinz, A., Scherrer-Rathje, M., \& Friedli, T. (2014). Turning sustainability into action: Explaining firms' sustainability efforts and their impact on firm performance. International Journal of Production Economics, 147(Part A), 73-84.

Sharma, H. K., \& Rana, P. K. (2014). Assessing the impact of hydroelectric project construction on the rivers of District Chamba of Himachal Pradesh in the Northwest Himalaya, India. Int. Res. J. Social Sci., 3(2), 21-25,

Silva, M. R. (2012). Survival strategies of the Tembe indigenous Indians of the upper Rio Guama land (TIARG), State of Pará, Brazil, in the era of carbon credits. PhD dissertation in management. Universidade de Tras-os-Montes and Alto Douro (UTAD).

Smolar-Žvanuta, N., \& Mikošb, M. (2013). The impact of flow regulation caused by hydropower dams on the periphyton community in the Soča River, Slovenia. Hydrological Sciences Journal, 59(5), 1-14.

Soini, K., \& Birkeland, I. (2014). Exploring the scientific discourse on cultural sustainability. Geoforum, 51, $213-223$.

Soito, J. L. S. (2011). Amazônia e a expansão da hidroeletricidade no Brasil: vulnerabilidades, impactos e desafios (Amazon and the expansion of hydroelectricity in Brazil: Vulnerability, impacts and challenges). Doctoral thesis at the Federal University of Rio de Janeiro, Brazil. UFRJ/COPPE.

Souza, W. F. L., Medeiros, P. R. P., Brandini, N., \& Knoppers, B. (2011a). Impactos de Barragens sobre os fluxos de Materiais na Interface Continente-Oceano (Impacts of dams on materials flows in the continent-ocean interface). Rev. Virtual de Quimica (Virtual Chemistry Journal), 3(2), 116-128.

Souza, A. S., Souza, J. B., Oliveira, L. C. O., \& Estevam, G. P. (2011b). Adequação ao sistema de tarifação de consumidores de energia elétrica (Adaptation to consumer pricing system of electricity). Omnia Exatas (Exact Omnia), 4(2), 43-62.

Souza, R. A., Miziara, F., \& Junior, P. M. (2013). Spatial variation of deforestation rates in the Brazilian Amazon: A complex theater for agrarian technology, agrarian structure and governance by surveillance. Land Use Policy, 30(1), 915-924.

Sühlsen, K., \& Hisschemöller, M. (2014). Lobbying the "Energiewende". Assessing the effectiveness of strategies to promote the renewable energy business in Germany. Energy Policy, 69, 316-325.

Tavera, R., \& Novelo, E. (2011). The periphyton of wetlands and agriculture Yucatan Maya. Portal scientific and refereed journals UNAM. National Autonomous University of Mexico-UNAM, 102, 40-45.

Tayşir, E. A., \& Pazarcik, Y. (2013). Business ethics, social responsibility and corporate governance: Does the strategic management field really care about these concepts? Procedia-Social and Behavioral Sciences, 99, 294-303.

Tinoco, J. E. P., \& Kraemer, M. E. P. (2008). Contabilidade e gestão ambiental (Accounting and environmental management) (2nd ed.). São Paulo: Atlas.

Tollefson, J., \& Gilbert, N. (2012). Earth summit: Rio report card. Nature International Weekly Journal of Science, 486, $20-23$.

Uhlmann, D. M. (2011). After the spill is gone: The Gulf of Mexico, environmental crime, and the criminal law. Michigan Law Review, 109(8), 1413-1461.

Umaña-Villalobos, G. (2014). Phytoplankton variability in Lake Fraijanes, Costa Rica, in response to local weather variation. Rev. Biol. Trop, 62(2), 483-494.

UNFCCC (United Nations Framework Convention on Climate Change). (2013). Kyoto Protocol. Retrieved from http://unfccc. int/kyoto_protocol/items/2830.php

Valerrama, Y., \& Moreno, L. (2012). Contabilidad de Gestión Ambiental en Empresas Constructoras. Impacto Y Efectos de su Uso. Centro de Investigación de Ciencias Administrativas Y Gerenciales (Environmental management accounting in construction companies. Impact and effects of their use. Research Center of Administrative Sciences and Management). CICAG, 9(1), 1-19.

Wagtendonk, A. J., \& Vermaat, J. E. (2014). Visual perception of cluttering in landscapes: Developing a low resolution GIS-evaluation method. Landscape and Urban Planning, 124, 85-92. 
Wang, P., Wolf, S. A., Lassoie, J. P., \& Dong, S. (2013). Compensation policy for displacement caused by dam construction in China: An institutional analysis. Geoforum, 48, 1-9.

Weilkiens, T., Weiss, C., \& Grass, A. (2011). Chapter 2-Basic principles of business management. OCEB certification guide (pp. 13-31). Boston: Morgan Kaufmann.

Wiengarten, F., Pagell, M., \& Fynes, B. (2013). ISO 14000 certification and investments in environmental supply chain management practices: Identifying differences in motivation and adoption levels between Western European and North American companies. Journal of Cleaner Production, 56, 18-28.

World Commission on Dams (WCD). (2000). Dams and development: A new framework for decision making. Retrieved from http://www.unep.org/dams/WCD/report/WCD_DAMS\%20report.pdf

$\mathrm{Xu}, \mathrm{X}$. , Tan, Y., Yang, G., Li, H., \& Su, W. (2011). Impacts of China's Three Gorges Dam Project on net primary productivity in the reservoir area. Science of the Total Environment, 409(22), 4656-4662.

Xu, X., Tan, Y., \& Yang, G. (2013a). Environmental impact assessments of the Three Gorges Project in China: Issues and interventions. Earth-Science Reviews, 124, 115-125.

Xu, Y., Zaelke, D., Velders, G. J. M., \& Ramanathan, V. (2013b). The role of HFCs in mitigating 21 st century climate change. Atmos. Chem. Phys., 13, 6083-6089.

Zhang, J., Fu, M., Zhang, Z., Tao, J., \& Fu, W. (2014). A trade-off approach of optimal land allocation between socio-economic development and ecological stability. Ecological Modelling, 272, 175-187. 